\title{
TRADE OPENNESS AND ECONOMIC GROWTH: A CAUSALITY TEST IN PANEL PERSPECTIVE
}

\author{
Jamilah Idris \\ Universiti Putra Malaysia \\ Zulkornain Yusop* \\ Universiti Putra Malaysia \\ Muzafar Shah Habibullah \\ Universiti Putra Malaysia
}

\begin{abstract}
Openness to trade has been one of the primary drivers stimulating growth. The goal of this particular study is to investigate the relationship between trade openness and economic growth in 87 selected countries which includes both Organizations for Economic Co-operation and Development (OECD) and developing countries for 1977-2011 periods. We used two measures of trade openness i.e. the ratio of trade openness (TO) typically spoke by exports plus imports in nominal value divided by GDP (nominal) which is commonly used in the literature, and trade openness in real (RO) which is defined as the sum of imports and exports in US\$ relative to GDP in purchasing power parity US\$ (real GDP). An empirical studywas conducted to determine the causal relationship between trade openness and growth in a panelperspective. We used a dynamic panel data estimation method i.e. the general method of moments (GMM). The empirical results reveal a bidirectional causal relationship for both developing and OECD countries. Our finding is consistent with the endogenous theory that increased openness leads to higher growth, which thus prompts expanded openness.
\end{abstract}

Keywords: Openness; Economic Growth; Dynamic Panel General Method of Moments (GMM).

\section{INTRODUCTION}

The linkage concerning trade openness and growth has long been a debatable matter in the worldwide trade literature. It has been strong fact that many countries have opened their economies for the purpose of economic development and growth. In the course of recent years, increase in world trade has arrived at the midpoint of percentage of 6 per year. This is double as high as the growth in the world yield. When the General Agreement on Tariffs and Trade (GATT) was signed in 1947, all member countries of the world trading system had gained from the eight rounds of multilateral trade liberalization.

\footnotetext{
*Corresponding author: Faculty of Economics and Management, Department of Economics, 43400 UPM Serdang, Selangor, Malaysia. Tel: 013-89467643 Email: zulkornain@upm.edu.my.
} 
In fact, the GATT final "Uruguay Round" which was completed in 1994 prompted the establishment of the World Trade Organization (WTO). WTO is aimed to improve the standard of living of people in the member countries, ensure full employment and broad increase in effective demand, enlarge production and trade of goods, increase the trade of services, ensure optimum utilization of world resources, protect the environment and promote the concept of sustainable development. WTO implements rules and provisions related to trade policy review mechanism, provides a platform to member countries to decide future strategies related to trade and tariff, provides facilities for implementation, administration and operation of multilateral and bilateral agreements of the world trade, administers the rules and processes related to dispute settlement and finally assists international organizations such as, IMF and IBRD for establishing coherence in Universal Economic Policy determination.

This study focuses on the causal relationship between trade openness and growth. Openness is considered an important tool for growth in both developing countries and developed countries (Dar \& Amirkhalkhali, 2003). Increased openness is believed to have positive impact on productivity, which in turn improves employment and real wages as a result of new investments (Krueger, 1985). It is possible that causality may also run from economic growth to openness.

The ratio for trade openness (TO) is typically represented by nominal of exports added by the nominal of imports divided by nominal GDP. This ratio is commonly used in the literature. The other trade measure is real openness $(R O)$. The real openness is calculated as imports plus exports in US\$ relative to GDP in purchasing power parity (PPP) of US\$ (real GDP). We could eliminate the distortions resulting from the relative price of nontradable goods in cross-country differences as we use openness in real instead of the conventional (nominal) openness.

This paper is organized as follows. First, the relationship between openness and economic growth is described, followed by a review of the literature on trade openness and economic growth. The subsequent section discusses the econometric methodology followed by reviews of data sources. The last two parts discuss the analysis and the results followed by the concluding remark.

\section{LITERATURE REVIEW}

In recent years, openness has played an increasingly important role in the growth. The Adam Smith and Ricardo traditional models explained that openness would promote specialization. Thus, countries specialize in the production of goods and services that they have advantages and export such goods and services. On the other hand, countries without such advantages will import from those countries and specialize in other types of goods and services. As a result, resources are more optimally allocated.

The theory of endogenous growth assumes that technology is developed internally. As an aftermath of openness, developing countries build their profit and productivity by utilizing new advances, consequently bringing about an expanded production (Jin, 2000). According to the endogenous growth theories, an increment in trade openness would positively improve technology and thus increase production. Additionally, trade 
openness may prompt an increment in development through a country information stock (Rivera-Batiz \& Romer, 1991). For example, developing countries can promote their growth by transferring knowledge from rich countries. Countries which are more open are more exposed to the advancement on the planet (Grossman \& Helpman, 1995).

A study by Levine and Renelt (1992) indicated that openness to trade would encourage foreign direct investment as a result of reduced tariffs, thus increasing long-term growth. In another previous study, Grossman and Helpman (1995) stated that a reduction in tariffs would positively affect the resources allocated to R\&D. In a microeconomic framework, exporting firms are more expert and technology oriented than non-exporting firms because exporting firms are more exposed to more intense competition as compared to those firms that focus only on the domestic market (López, 2005).

A review of the cross-sectional literature showed that previous studies used different methods and data from various countries to find causality between openness and economic growth. However, some studies observed no causality at all. Among the researchers addressing the relationship between openness and economic growth are Zeren and Ari (2013), who analyzed openness and growth among the G7 countries i.e. Germany, France, Canada, Japan, Italy, the United States, and the United Kingdom for 1970-2011 periods. These researchers applied the generally significantly produced Granger non-causality test. Those effects uncovered a bidirectional causal relationship between openness and economic growth.

Gries and Redlin (2012) using general method of moments (GMM) estimation for 158 countries from 1970 to 2009, found a positive causal relationship from openness to growth in the long term.

Bidirectional relationship between openness to trade and growth is found mainly for industrialized countries only when the countries are classified according to income groups. However, in fewer developed countries, negative causality has been observed. Study done by Akilou (2013) investigated the linkages of trade openness and economic growth. They focused on countries in West African Economic and Monetary Union (WAEMU). Their results showed that economic growth did not cause trade openness in Côte d'Ivoire at the 10\% level of significance. Saad (2012) used vector error correction models (VECMs) and Granger causality in examining data from 1970 to 2011 and their results for Lebanon truly follow the export-led growth hypothesis.

Hatemi (2002) tested export-led growth hypothesis for Japan during 1960-1999 periods. The author used Granger causality tests utilizing the bootstrap technique of simulation. The Outcomes demonstrated bidirectional causality between exports as well as growth. Meanwhile, Awokuse (2007) utilized the Granger (1969) and Sims (1972) causality tests for Bulgaria, the Czech Republic, Poland and Eastern European countries, and the comes suggested that trade pushes growth. Reizman, Summers, and Whiteman (1996) utilized the Granger causality test for Algeria, Egypt, and Tunisia. They discovered that exports bring growth for Algeria, Egypt, and Tunisia but not for Israel, Jordan, Morocco, Sudanese as well as Turkey. Kurt and Berber (2008) used VAR techniques for Turkey utilizing quarterly information data for 1989-2003 periods. The Outcomes 
demonstrated bidirectional causality between economic growth and openness. Dar and Amirkhalkhali (2003) studied 19 OECD nations for 1971-1999 periods. Their results proposed that openness generally caused economic growth.

Bahmani-Oskooee and Niromand (1999) conducted Granger causality tests for 20 nations and discovered both positive and negative causality. Chow (1987) found bidirectional causality in six situations and unidirectional causality in one case of 8 industrialized nations. Jung and Marshall (1985) did the Granger causality test for 37 nations from 1951 with 1981. They observed unidirectional causality of exports on growth. However, Harrison (1996), who utilized the estimators for fixed-effect, found a stronger impact of different openness indicators. Meanwhile, Wacziarg and Welch (2003) refined the work of Sachs and Warner (1995) on three directions by updating, expanding refining openness. They discovered impacts of trade on the growth.

\section{METHODOLOGY}

As our focus is to investigate the causal linkage between trade openness and growth, panel data as well as the dynamic panel system GMM are used for OECD and developing countries from 1977 to 2011. The dynamic relationship, in general is characterized by the presence of lagged regressors. It is included in the causality-based variable GDP per capita (Gdp) and trade openness ( $T O \& R O), \mathrm{Open}_{\mathrm{i}, \mathrm{j}, \mathrm{t}-\mathrm{k}}$ :

$$
\begin{aligned}
& \mathrm{GDP}_{\mathrm{it}}=\propto+\sum_{\mathrm{k}=1}^{\mathrm{m}} \partial_{\mathrm{j}} \mathrm{GDP}_{\mathrm{i}, \mathrm{t}-\mathrm{k}}+\sum_{\mathrm{k}=1}^{\mathrm{n}} \beta_{1} \mathrm{TO}_{\mathrm{i}, \mathrm{t}-\mathrm{k}}, \mathrm{RO}_{\mathrm{i}, \mathrm{t}-\mathrm{k}}+\mathrm{u}_{\mathrm{ijt}} \\
& \mathrm{TO}_{\mathrm{it}}, \mathrm{RO}_{\mathrm{it}}=\Theta+\sum_{\mathrm{k}=1}^{\mathrm{m}} \sigma_{\mathrm{j}} \mathrm{TO}_{\mathrm{i}, \mathrm{t}-\mathrm{k}}, \mathrm{RO}_{\mathrm{i}, \mathrm{t}-\mathrm{k}}+\sum_{\mathrm{k}=1}^{\mathrm{n}} \partial_{1} \mathrm{GDP}_{\mathrm{i}, \mathrm{t}-\mathrm{k}}+\mathrm{w}_{\mathrm{ijt}}
\end{aligned}
$$

As $\mathrm{t}=1,2 \ldots \mathrm{T}$ is time; $\mathrm{i}=1,2 \ldots \mathrm{N}$ is the cross-section and $\mathrm{m} \& \mathrm{n}$ is the number of lagged and $\mathrm{j}=\mathrm{TO} \& \mathrm{RO}$.

$\mathrm{u}_{\mathrm{it}}=\mathrm{w}_{\mathrm{i}}+\lambda_{\mathrm{t}}+\mathrm{v}_{\mathrm{it}}$

Where

$\mathrm{u}_{\mathrm{i}} \sim \operatorname{IID}\left(0,{\sigma_{\mathrm{u}}}^{2}\right)$ : unobserved country-specific effect

$\lambda_{\mathrm{it}} \sim \operatorname{IID}\left(0, \sigma_{\mathrm{u}}^{2}\right)$ : period-specific effects

$\mathrm{v}_{\text {it }} \sim \operatorname{IID}\left(0, \sigma_{\mathrm{u}}^{2}\right)$ : error term

These studies employ an element of dynamic panel data and GMM estimation. Arellano and Bond (1991) recommended a dynamic panel data GMM estimator (IV estimator). The estimations of Arellano and Bond (1991) began by transforming all regressors from GMM (Hansen, 1982) and designed the Arellano and Bond estimator for small $\mathrm{T}$ and 
large $\mathrm{N}$ panels. A stun to nation, fixed effects demonstrates that the error term (vast $\mathrm{T}$ ) will decay over the long haul. One would not utilize the estimator for Arellano and Bond, for instance if the relationship of the variable in lagged dependent with the error term is inconsequential (Roodman, 2006). The two estimators which are proposed by Arellano and Bond are one- and two-stage estimators. The ideal estimator is the estimator in two-stage. However, the J test presented by Hansen (1982) for overidentifying confinements is performed. The step is critical for testing the model determinations and the suitability of the instruments. The test for secondorder serial correlation suggests that the error term is serially corresponded and takes after a moving-normal methodology. This brought about the dismissal of laggedvalues as appropriate instruments for the GMM estimation. As in the over-ID tests, neglecting to reject the null hypothesis of the nonappearance of second-order serial relationship are support for the validity of the model.

The instruments variables are utilized as the issue to address the conceivable endogeneity in the explanatory variable and the connection between the new error term and the lagged dependent variable. Restricted types of synchronization and reverse causation were permitted on the grounds that there is strict endogeneity if, for instance, the explanatory variable at all lag and leads is uncorrelated with the error term. The presumption is that the explanatory variables are feebly exogenous and that the error term is not connected. In terms of the consistency for the GMM estimator, it relies on upon the legitimacy of the instruments utilized, which will be considered as a part of two detail tests in view of Arellano and Bond (1991), Arellano and Bover (1995) and Blundell and Bond (1998). To test for over-identifying limitations, the Hansen test is

utilized. Meanwhile, the joint null hypothesis is utilized to figure out if the instruments are substantial (Arellano and Bond, 1991). On the off chance that no relationship with the error term is discovered, this outcome may test the second-order serial hypothesis of no connection in the error term.

\section{DATA}

Our study investigates the linkages between openness of trade and economic growth in 87 selected countries, including both developing and OECD countries from 1977 to 2011. The economic growth is measured conventionally using per capita in GDP constant 2005 US dollars. The most common measurement of the trade openness ratio (TO) is exports plus imports divided by GDP in nominal value, whereas real openness $(R O)$ refers to exports plus imports divided by PPP-adjusted GDP (real GDP). Using real openness rather than trade openness usually measure of trade, which is eliminates the distortions resulting from the differences cross-country price relative in the relative of goods which is non-tradable. All of the variables cited are employed with their natural logarithms. The data used are sourced from Penn World 7.0 provided by Heston, Summers, and Aten (2011). 


\section{EMPIRICAL FINDINGS}

To determine the causal relationship between trade openness and economic growth, the GMM panel causality test was employed. The Blundell-Bond system GMM as described in Blundell and Bond (1998) and Bond (2002) was used in the process of testing the presence of lagged dependent variables in the estimated panel. The BlundellBond procedure refined the application of Arellano and Bond (1991) and Arellano and Bover (1995). One-step and two-step variants are used in the difference GMM and system GMM approaches. Although the two-step estimator is more accuracy, it is believed that the two-step estimate of the difference GMM standard error has a severe downward bias. The two-step estimator in the system GMM approach is more accurate than the one-step estimator. According to Blundell and Bond (1998), the asymptotic standard errors in the restricted samples, can be seriously biased downward with the estimator in two steps GMM. This study chose to use the two-step system GMM; thus, subsequent discussion will focus on this method.

Table 1 presents the results of the panel causality test for OECD countries. The result is robust and consistently exhibits bidirectional causality running from trade openness (TO) and real openness $(R O)$ to economic growth $(G d p)$. This causality is observed at the 5\% significance level. In the case of developing countries, the result is also robust and reveals a bidirectional causal relationship between trade openness and growth (Table 2). The results indicate that growth in developing countries is caused by the openness and that a boost in economic performance is one of the causes of increased openness.

Overall, the diagnostic test results in Tables 1 and Table 2 propose that the test of firstand second-request autocorrelation of the residual reported the standard ordinary distribution estimations of AR (1) and AR (2). The test for first-order autocorrelation AR (1) rejected the null hypothesis; the $p$-values statistics were at the 5 percent and 10 percent significant levels. The test for second-order autocorrelation AR (2) are neglected to reject the null hypothesis of no autocorrelation. The statistics as well as the $p$-values reported demonstrated the likelihood of accurately rejected the null hypothesis. Thus, the AR (1) and AR (2) tests backed the legitimacy estimator of the system GMM. The insignificant of $p$-values for the Hansen test demonstrating that the model does not experience suffer of over-identifications. Furthermore, the Wald test of regressors of the joint significance is measurably critical in the estimated models at the 5 percent level. Therefore, the findings uncover a bidirectional causal relationship between trade openness and economic growth. For OECD and developing countries, a causal relationship exists both from trade openness to economic growth and the other way around.

Table 1: Panel Causality Test Results for 28 OECD Countries

\begin{tabular}{ccccc}
\hline \hline \multirow{2}{*}{ Variables } & \multicolumn{4}{c}{ Dependent Variable } \\
\cline { 2 - 5 } & $\mathbf{G D P}_{\mathbf{t}}$ & $\mathbf{T O}_{\mathbf{t}}$ & $\mathbf{G D P}_{\mathbf{t}}$ & $\mathbf{R O}_{\mathbf{t}}$ \\
\hline $\mathrm{GDP}_{\mathrm{t}-1}$ & $1.4287^{* *}$ & $1.2130^{* *}$ & $1.3918^{* *}$ & $1.8812^{* *}$ \\
& $(0.0934)$ & $(0.1438)$ & $(0.1022)$ & $(0.3947)$ \\
$\mathrm{GDP}_{\mathrm{t}-2}$ & -0.2008 & $-0.6623^{* *}$ & -0.0333 & $-1.4666^{* *}$ \\
& $(0.2109)$ & $(0.1715)$ & $(0.3029)$ & $(0.5547)$ \\
\hline
\end{tabular}


Table 1: Panel Causality Test Results for 28 OECD Countries (con't)

\begin{tabular}{|c|c|c|c|c|}
\hline \multirow{2}{*}{ Variables } & \multicolumn{4}{|c|}{ Dependent Variable } \\
\hline & $\mathbf{G D P}_{\mathrm{t}}$ & $\mathrm{TO}_{\mathrm{t}}$ & $\mathbf{G D P}_{\mathrm{t}}$ & $\mathbf{R O}_{\mathrm{t}}$ \\
\hline $\mathrm{GDP}_{\mathrm{t}-3}$ & $\begin{array}{c}-0.2541 \\
(0.1432)\end{array}$ & $\begin{array}{c}0.2790 \\
(0.1682) \\
\end{array}$ & $\begin{array}{c}-0.3740 \\
(0.2222)\end{array}$ & $\begin{array}{c}0.4035 \\
(0.4248) \\
\end{array}$ \\
\hline Independent & $\mathbf{T O}_{\mathrm{t}}$ & $\mathbf{G D P}_{t}$ & $\mathbf{R O}_{\mathrm{t}}$ & $\mathbf{G D P}_{t}$ \\
\hline $\mathrm{TO}_{\mathrm{t}-1}$ & $\begin{array}{c}0.2304^{* *} \\
(0.0699)\end{array}$ & $\begin{array}{l}-0.5362^{* *} \\
(0.2724)\end{array}$ & & \\
\hline $\mathrm{TO}_{\mathrm{t}-2}$ & $\begin{array}{l}-0.5484^{* *} \\
(0.0906)\end{array}$ & $\begin{array}{l}2.3835 * * \\
(0.5381)\end{array}$ & & \\
\hline $\mathrm{TO}_{\mathrm{t}-3}$ & $\begin{array}{l}0.3151 * * \\
(0.0948)\end{array}$ & $\begin{array}{l}-1.8395 * * \\
(0.3888)\end{array}$ & & \\
\hline $\mathrm{RO}_{\mathrm{t}-1}$ & & & $\begin{array}{l}0.3606^{* *} \\
(0.1824)\end{array}$ & $\begin{array}{l}-0.4662 \\
(0.3607)\end{array}$ \\
\hline $\mathrm{RO}_{\mathrm{t}-2}$ & & & $\begin{array}{c}-0.5445 \\
(0.3303)\end{array}$ & $\begin{array}{l}1.9099 * * \\
(0.7109)\end{array}$ \\
\hline $\mathrm{RO}_{\mathrm{t}-3}$ & & & $\begin{array}{c}0.1716 \\
(0.1889)\end{array}$ & $\begin{array}{l}-1.4364 * * \\
(0.5016)\end{array}$ \\
\hline Constant & $\begin{array}{c}0.2940 \\
(0.1655) \\
\end{array}$ & $\begin{array}{c}0.5802 \\
(0.4439) \\
\end{array}$ & $\begin{array}{c}0.1760 \\
(0.1559) \\
\end{array}$ & $\begin{array}{c}0.6987 \\
(0.3404) \\
\end{array}$ \\
\hline \multicolumn{5}{|l|}{ Diagnostic: } \\
\hline Observation & 102 & 102 & 99 & 102 \\
\hline $\mathrm{AR}(1)$ & $-2.16^{* *}$ & $-2.08 * *$ & -1.92 & -1.51 \\
\hline $\operatorname{AR}(2)$ & -1.45 & -0.01 & -1.48 & 0.63 \\
\hline Hansen Test & 0.1640 & 0.1130 & 0.1270 & 0.4900 \\
\hline Wald Test & $\begin{array}{c}48.43^{* *} \\
(0.0000)\end{array}$ & $\begin{array}{l}23.19 * * \\
(0.0000)\end{array}$ & $\begin{array}{c}17.39 * * \\
(0.0006)\end{array}$ & $\begin{array}{r}8.59 * * \\
(0.0353)\end{array}$ \\
\hline Remarks & $\mathrm{T} \leftrightarrow \mathrm{Y}$ & $\mathrm{Y} \leftrightarrow \mathrm{T}$ & $\mathrm{T} \leftrightarrow \mathrm{Y}$ & $\mathrm{Y} \leftrightarrow \mathrm{T}$ \\
\hline \multicolumn{5}{|c|}{$\begin{array}{l}\text { Notes: The round figure is a standard error. Asterisk ***, ** denotes statistically at } 1 \% \text { and } 5 \% \text { significar } \\
\text { level. The AR (1) and AR (2) figures are z-value, Wald test and Hansen test are p-values. Y and } \\
\text { denote Gdp and TO/RO, respectively. }\end{array}$} \\
\hline \multicolumn{5}{|c|}{$\begin{array}{c}\text { Table 2: Panel Causality Test Results for } 59 \text { Selected Developing Countries } \\
\text { Dependent Variable }\end{array}$} \\
\hline Variables & $\mathbf{G D P}_{\mathrm{t}}$ & TO & GDP & $\mathbf{R O}_{\mathbf{t}}$ \\
\hline $\mathrm{GDP}_{\mathrm{t}-1}$ & $\begin{array}{l}1.4647^{* *} \\
(0.1093)\end{array}$ & $\begin{array}{r}0.7069 * * \\
(0.1221)\end{array}$ & $\begin{array}{l}1.5971^{* *} \\
(0.1003)\end{array}$ & $\begin{array}{r}0.4607 * * \\
(0.0866)\end{array}$ \\
\hline $\mathrm{GDP}_{\mathrm{t}-2}$ & $\begin{array}{l}-0.6864 * * \\
(0.1566)\end{array}$ & $\begin{array}{l}-0.1003 \\
(0.1122)\end{array}$ & $\begin{array}{l}-0.6239 * * \\
(0.1439)\end{array}$ & $\begin{array}{c}0.2256 \\
(0.2066)\end{array}$ \\
\hline $\mathrm{GDP}_{\mathrm{t}-3}$ & $0.2189 * *$ & -0.0633 & 0.0484 & -0.0461 \\
\hline & $(0.1724)$ & $(0.1354)$ & $(0.0869)$ & (0.1997) \\
\hline Independent & $\mathbf{T O}_{\mathrm{t}}$ & $\mathbf{G D P}_{t}$ & $\mathbf{R O}_{\mathrm{t}}$ & $\mathbf{G D P}_{\mathrm{t}}$ \\
\hline $\mathrm{TO}_{\mathrm{t}-1}$ & $\begin{array}{c}0.2326 * * \\
(0.0726)\end{array}$ & $\begin{array}{c}0.3351 \\
(0.1911) \\
\end{array}$ & & \\
\hline
\end{tabular}


Table 2: Panel Causality Test Results for 59 Selected Developing Countries (con't)

\begin{tabular}{ccccc}
\hline \hline Independent & $\mathbf{T O}_{\mathbf{t}}$ & $\mathbf{G D P}_{\mathbf{t}}$ & $\mathbf{R O}_{\mathbf{t}}$ & $\mathbf{G D P}_{\mathbf{t}}$ \\
\hline $\mathrm{TO}_{\mathrm{t}-2}$ & -0.1262 & $-0.5309^{* *}$ & & \\
$\mathrm{TO}_{\mathrm{t}-3}$ & $(0.0779)$ & $(0.1955)$ & & \\
& 0.0364 & $0.3652^{* *}$ & & \\
$\mathrm{RO}_{\mathrm{t}-1}$ & $(0.0507)$ & $(0.0961)$ & & 0.5683 \\
& & & 0.0860 & $(0.3066)$ \\
$\mathrm{RO}_{\mathrm{t}-2}$ & & & $-0.1512)$ & $-1.1621^{* *}$ \\
$\mathrm{RO}_{\mathrm{t}-3}$ & & & $(0.1293)$ & $(0.5704)$ \\
& & & $0.1231^{* *}$ & 0.4722 \\
Constant & -0.4806 & 0.6877 & $(0.0304)$ & $(0.3721)$ \\
& $(0.2559)$ & $(0.4623)$ & -0.2470 & $2.4604^{* *}$ \\
\hline Diagnostic: & & & $(0.2296)$ & $(0.4830)$ \\
Observation & 209 & 210 & & \\
$\mathrm{AR}(1)$ & $-2.88^{* *}$ & $-2.76^{* *}$ & $-2.33^{* *}$ & -1.88 \\
$\mathrm{AR}^{*}$ (2) & 0.46 & -0.23 & -0.12 & -0.19 \\
Hansen Test & 0.2290 & 0.5690 & 0.2390 & 0.4270 \\
Wald Test & $14.27^{* *}$ & $15.53^{* *}$ & $18.11^{* *}$ & $10.48^{* *}$ \\
& $(0.0020)$ & $(0.0014)$ & $(0.0004)$ & $(0.0149)$ \\
Remarks & $\mathrm{T} \leftrightarrow \mathrm{Y}$ & $\mathrm{Y} \leftrightarrow \mathrm{T}$ & $\mathrm{T} \leftrightarrow \mathrm{Y}$ & $\mathrm{Y} \leftrightarrow \mathrm{T}$ \\
\hline \hline
\end{tabular}

Notes: The round figure is a standard error. Asterisk ***,** denotes statistically at $1 \%$ and $5 \%$ significant level. The AR (1) and AR (2) figures are z-value, Wald test and Hansen test are indicated by p-values. Y and T denote Gdp and TO/RO, respectively.

\section{CONCLUSIONS}

Our empirical investigation has generally reached conclusive results using crosssectional specifications. Openness yields a significantly positive coefficient which proves that trade openness is good for growth. Our study investigated the causal linkage between trade openness and economic growth. The causality test using dynamic panel GMM was used for the main purpose of these studies. The test statistics depended on the individual Wald statistics of panel GMM. The empirical results revealed bidirectional causality between openness, trade and economic growth. Overall, it may be reasonable to conclude that openness, by leading to fewer prices, good information and technologies upgrade plays an important role in promoting growth. The evidence indicates the importance of a country's dependence on foreign trade to increase growth in OECD and developing countries, thereby increasing openness in turn. However, such reliance must be done by appropriate policies, for example, the investment, education, and financial as well as macroeconomic policies to promote better growth results. In conclusion, high levels of openness in countries are determined by growth and by high economic performance. 


\section{REFERENCE}

Akilou, A. (2013). Is there a causal relation between trade openness and economic growth in the WAEMU countries? International Journal of Economics and Finance, 5, 151-156.

Arellano, M., \& Bond, S. (1991).Some tests of specification for panel data: Monte Carlo evidence and an application to employment equations. Review of Economic Studies, 58(2), 277-297. doi: 10.2307/2297968

Arellano, M., \& Bover, O. (1995).Another look at the instrumental variable estimation of error-components models. Journal of Econometrics, 68(1), 29-51. doi: 10.1016/0304-4076(94)01642-D

Awokuse, T. O. (2007). Causality between exports, imports, and economic growth: Evidence from transition economies. Economics Letters, 94(3), 389-395. doi: 10.1016/j.econlet.2006.08.025

Bahmani-Oskooee, M., \& Niromand, F. (1999). Openness and economic growth: An empirical investigation. Applied Economics Letters, 6(9), 557-561.

Blundell, R., \& Bond, S. (1998). Initial conditions and moment restrictions in dynamic panel-data models. Journal of Econometrics, 87(1), 115-143. doi: 10.1016/S0304-4076(98)00009-8

Chow, P. C. Y. (1987). Causality between exports and industrial development: empirical evidence from the nic's. Journal of Development Economics, 26(1), 55-63.

Dar, A., \& Amirkhalkhali, S. (2003). On the impact of trade openness on growth: Further evidence from OECD countries. Applied Economics, 35(16), 1761-1766. doi: 10.1080/0003684032000129020

Granger, C. W. J. (1969). Investigating causal relations by econometric models and cross-spectral methods. Econometrica, 37(3), 424-438. doi: 10.2307/1912791

Gries, T., \& Redlin, M. (2012). Trade openness and economic growth: A panel causality analysis. Centre for International Economics, Canberra, Australia Working paper series, no. 2011-06.

Grossman, G., \&Helpman, E. (1995).Innovation and growth in the global economy. Cambridge, MA: The MIT Press.

Hansen, L. (1982). Large sample properties of generalized method of moment's estimators. Econometrica, 50(4), 1029-1054.

Harrison, A. (1996). Openness and growth: A time-series, cross-country analysis for developing countries. Journal of Development Economics, 48(2), 419-447. doi: 10.1016/0304-3878(95)00042-9

Hatemi, J. A. (2002). Export performance and economic growth nexus in Japan: A bootstrap approach. Japan and the World Economy, 14(1), 25-33. doi: 10.1016/S0922-1425(01)00071-8

Heston, A., Summers, R., \& Aten, B. (2011). Penn World table version 7.0. Philadelphia, PA: Center for International Comparisons of Production, Income and Prices at the University of Pennsylvania. 
Jin, J. C. (2000). Openness and growth: An interpretation of empirical evidence from East Asian countries. The Journal of International Trade and Economic Development, 9(1), 5-17. doi: 10.1080/096381900362517 Jung, S. W., \& Marshall, P. J. (1985).Exports, growth and causality in developing countries. Journal of Development Economics, 18(1), 1-12.

Krueger, A. (1985). The experiences and lessons of Asia's super exporters. In V. Corbo, A. Krueger, \& F. Ossa (Eds.), Exports-Oriented Development Strategies: The Success of Five Newly Industrialising Countries. Boulder, CO: Westview Press. Kurt, S., \& Berber, M. (2008).Openness in Turkey and economic growth. Atatürk University Economic and Administrative Journal, 22(2), 57-79.

Levine, R., \&Renelt, D. (1992). A sensitivity analysis of cross-country growth regressions. American Economic Review, 82(4), 942-963.

López, R. A. (2005). Trade and growth: Reconciling the macroeconomic and microeconomic evidence. Journal of Economic Surveys, 19(4), 623-647. doi: 10.1111/j.0950-0804.2005.00264.x

Reizman, R. G., Summers, P. M., \& Whiteman, C. H. (1996). The engine of growth or its handmaiden? A time series assessment of export-led growth. Empirical Economics, 21(1), 77-113. doi: 10.1007/BF01205495

Rivera-Batiz, L. A., \& Romer, P. M. (1991). Economic integration and endogenous growth. The Quarterly Journal of Economics, 106(2), 531-555.

Roodman, D. (2006). How to do xtabond2: An introduction to "difference" and "system" GMM in Stata. Washington, DC: Center for Global Development.

Saad, W. (2012). Causality between economic growth, export, and external debt servicing: The case of Lebanon. International Journal of Economics and Finance, 4(11), 134-143. doi: 10.5539/ijef.v4n11p134

Sachs, J.-D., \& Warner, A.-M. (1995). Natural resource abundance and economic growth. NBER working paper no. 5398.

Sims, C. (1972). Money, income and causality. American Economic Reviews, 2(4), 540552.

Wacziarg, R., \& Welch, K. H. (2003).Trade liberalization and growth: New evidence. NBER working paper no. 10152.

Zeren, F., \& Ari, A. (2013). Trade openness and economic growth: A panel causality test. International Journal of Business and Social Science, 4(9), 317-324. 